\title{
A talajok mechanikai összetétel vizsgálata pipettás ülepítéses módszerrel: a hazai és a nemzetközi szabvány szerinti eljárások összehasonlítása és konverziója
}

\author{
${ }^{1}$ MAKÓ András - ${ }^{1,2 *}$ HeRnÁdi Hilda - ${ }^{1}$ BARNA Gyöngyi - ${ }^{3}$ BALÁzs Réka - \\ ${ }^{1}$ MolnÁR Sándor - ${ }^{4}$ LABANCZ Viktória $-{ }^{1,2}$ TóTH Brigitta - ${ }^{1}$ BAKACSI Zsófia \\ ${ }^{1}$ MTA ATK, Talajtani és Agrokémiai Intézet, Budapest \\ ${ }^{2}$ PE GK, Növénytermesztéstani és Talajtani Tanszék, Keszthely \\ ${ }^{3}$ MTA CSFK, Földtani és Geokémiai Intézet, Budapest \\ ${ }^{4}$ SZIE MKK, Környezettudományi Intézet, Talajtani és Agrokémiai Tanszék, Gödöllő
}

\section{Bevezetés}

A mechanikai összetételt (MÖ) és a fizikai féleséget (textúra), mint a különböző méretű elemi talajrészecskék eloszlását jellemző kvantitatív és kvalitatív jellemzőket, a talajok legfontosabb tulajdonságai közt tarthatjuk számon. A MÖ a talajok számos egyéb tulajdonságát befolyásolhatja (MAKÓ et al., 2017b) és a talajok osztályozása vagy a földminősítés során is fontos diagnosztikai kritérium (SZABOLCS et al., 1966; JASSÓ et al., 1989; TóTH, 2009; IUSS WORKING GROUP WRB, 2015). A MÖ vizsgálatok változatos módszertanát a talajtan számos tudományterülete és a társtudományok (földrajztudomány, geokémia, talajmechanika, hidrológia stb.) széles köre alkalmazza. Éppen a MÖ vizsgálatok általános elterjedtsége az oka annak, hogy napjainkban párhuzamosan számos mérési módszer létezik, e módszerek különféle mintaelőkészítési eljárásokat javasolnak, illetve a mérési eredmények változatos szemcseméret-kategóriák százalékos megoszlását mutatják be, melyeket (országonként vagy tudományterületenként) eltérő módon értékelnek, különböző textúra-csoportokat (fizikai féleség kategóriákat) képezve.

A fentiek miatt fontos kiemelni, hogy a MÖ eredmények közlése során minden esetben részletesen közölni kell a vizsgálatok során alkalmazott előkészítési eljárásokat, a mérési módszert, a vizsgálatokhoz használt mérőmüszert (típus, tartozékok, müszerbeállítások stb.), illetve a mért szemcseméret-csoportok (pl. agyag-, por-, iszapfrakció) mérethatárait és az egyes textúra-csoportok (pl. homokos vályog, agyagos vályog stb.) képzésének módszertanát. Fontos megismerni továbbá az alkalmazott eljárások előnyeit és korlátait, a mérési eredmények összehasonlíthatóságát más, általánosan használt módszerek eredményeivel (SHEIN,

Postai cím: HeRNÁdi HILDA, PE Georgikon Kar, 8360. Keszthely, Deák Ferenc u. 16.

E-mail: hhilduci@gmail.com

A cikk a Creative Commons Attribution-NonCommercial 4.0 International License (https://creativecommons.org/licenses/by-nc/4.0) feltételei szerint publikált Open Access közlemény, melynek szellemében a cikk nem kereskedelmi célból bármilyen médiumban szabadon felhasználható, megosztható és újraközölhető, feltéve, hogy az eredeti szerző és a közlés helye, illetve a CC License linkje és az esetlegesen végrehajtott módosítások feltüntetésre kerülnek. 
2009; RYŻAK \& BIEGANOWSKI, 2011; SOCHAN et al., 2015; MAKÓ et al., 2017a,b). A hazai talajtani gyakorlatban legáltalánosabban használt az ún. „pirofoszfátos szitás-ülepítéses, pipettás” módszer (MSZ-08-0205-78) (a továbbiakban „MSZ” módszer), míg a nemzetközi szabványok közül a korábbi (ISO/DIS 11277:1994; továbbiakban „ISO/DIS”), illetve az újabb (ISO 11277:2009(E); továbbiakban „ISO”) szitás-ülepítéses, pipettás módszerek a legismertebbek.

A MÖ vizsgálata során a mérés első lépése - a durva vázrészek (>2 $\mathrm{mm})$ eltávolítása után - a talajaggregátumok roncsolása elemi alkotóelemekké, illetve az elemi részecskék tartós diszpergálása. A talajok kötőanyagként általában szerves anyagokat, vas-(oxi)hidroxidokat és karbonátokat tartalmaznak, melyek különféle kémiai előkezelésekkel a részecskék felületéről leoldhatók és a talajszuszpenzióból eltávolíthatók (GEE \& BAUDER, 1986). A kémiai előkezelések különfélék lehetnek. A humuszanyagok, mint legfőbb szerkezetképző komponensek eltávolítására általában hidrogén-peroxid oldatot használnak, ami egyes módszereknél nagyon híg koncentrációjú (1-3\%-os) (MATHIEU \& PIELTAIN, 2003), a régebbi ún. „nemzetközi A módszernél" $6 \%$-os (Di GLÉRIA et al., 1957), míg az ISO/DIS és ISO módszerek esetében 30\%-os. A karbonátok eltávolítása hagyományosan általában híg (0,05 M) sósavval történik (ld. „Asztapov módszer”) (DI GLÉRIA et al., 1957; KACHINSKY, 1965); az ISO/DIS és ISO módszertan az 1 M sósav oldat használatát javasolja opcionálisan (amennyiben a talaj tömegszázalékos mésztartalma 2\%-nál nagyobb). A francia módszertan a $10 \%$-nál nagyobb $\mathrm{CaCO}_{3}$ tartalmú talajokban a mész kivonására az erőteljesen roncsoló sósav helyett $\mathrm{KCl}$ oldat hozzáadását ajánlja a mikroaggregátumok dezaggregálására (MATHIEU \& PIELTAIN, 2003). A talajrészecskéket összetapasztó vas-(oxi)hidroxidok eltávolítására az ISO/DIS és ISO módszerek - opcionálisan - Na-ditionit hozzáadását javasolják Na-citrát-Nabikarbonát puffer közegben. Számos hazai és nemzetközi tapasztalat azt mutatja, hogy a kémiai előkezelésekkel nemcsak a talajaggregátumokat választjuk szét, hanem - az előkezelés módjától függően - bizonyos talajásványokat is elroncsolhatunk, illetve kioldhatunk a talajból (LAVKULICS \& WIENS, 1970; MAKÓ et al., 2002; MiKUTTA et al., 2005; BALÁZS et al., 2011; SCHULTE et al., 2016).

A kémiai előkezelések során a további cél az - aggregátumokból felszabadított - elemi részecskék diszpergálása a negatív töltésủ adszorpciós helyek nagy elektronegativitású kationokkal (alkálifém kationok, általában $\mathrm{Na}^{+}$vagy $\mathrm{Li}^{+}$ionok) történő telítésével. Az adszorbeált alkálifém ionok nagy hidrát burkuk segítségével megakadályozzák a részecskék újbóli összetapadását. Az Egyesült Államokban, Oroszországban és több európai országban egyaránt elterjedt a Na-pirofoszfát alkalmazása az előkezelések során. A Na-pirofoszfát $\mathrm{Na}^{+}$ionja lecseréli a $\mathrm{Ca}^{++}$ ionokat a talajkolloidok felületéről, peptizáló hatásával elősegíti az elemi részecskék tartós diszpergált állapotának kialakulását. Ugyanakkor feltehetőleg némiképp képes megbontani a talajban ragasztóanyagként jelenlévő Ca-vegyületek (Ca-humát, -karbonát stb.) kötéseit is. Ez a tapasztalat vezethetett el oda, hogy némely módszertan (mint például az MSZ módszer is) előkészítésként - az egyéb kémiai előkészítő eljárások teljes elhagyásával - kizárólag a Na-pirofoszfátos előkezelést alkalmazza, melynek során a talajszuszpenzióhoz hozzáadandó Napirofoszfát oldat mennyiségét az Arany-féle kötöttségi szám függvényében 
határozzák meg. A felszabaduló $\mathrm{Ca}^{++}$ionok vízben oldhatatlan Ca-pirofoszfát formájában megkötődnek, a szuszpenzió szilárd fázisában a homokfrakció mennyiségét - mesterségesen - megnövelve (KACHINSKY, 1965; MIKUTTA et al., 2005). A Na-pirofoszfáthoz hasonló hatású diszpergálószer az ISO/DIS és ISO módszerek által ajánlott Na-hexametafoszfát, vagy a régebbi szabványok által a kis mésztartalmú talajok előkezelésére az ún. „Vageler előkészítés” során javasolt Likarbonát is (DI GLÉRIA et al., 1957). A régi nemzetközi szabvány (,nemzetközi A módszer") diszpergáló szerként 1 M Na-hidroxid oldat hozzáadását írja elő (DI GLÉRIA et al., 1957). Egyes amerikai módszerkönyvek kémiai diszpergálásra 120\%-os ammónium-hidroxid oldat használatát ajánlják (SHEIN, 2009).

A MÖ vizsgálatok során a kémiai diszpergálást a mechanikai diszpergálás követi. Ez általában a talajszuszpenzió különböző ideig történő rázatását vagy keverését jelenti különböző típusú eszközökkel. Az ultrahangos diszpergálást leginkább a lézerdiffrakciós MÖ méréseknél alkalmazzák, az ülepítéses módszereknél ritkábban használatosak (GENRICH \& BREMNER, 1972; SOCHAN et al., 2012; 2015).

A MÖ vizsgálatok következő lépése a részecskék különböző mérettartományú frakciókba történő elkülönítése és az egyes frakciókba eső mennyiségek meghatározása. A szétválasztandó frakciók száma és mérettartománya országonként és tudományterületenként nagy változatosságot mutat (RODERICK, 1966; NEMES et al., 1999). A legáltalánosabb az agyag-, por- és homokfrakciók elkülönítése, illetve e „föfrakciók” ,alfrakciókra” (pl. finom por, durva por stb.) történő megosztása. Az agyagfrakció felső mérethatára általában 0,002 mm (pl. MSZ; JURY et al., 1991; ISO), de az orosz talajtani iskola általában a 0,001 mm-es mérethatárt fogadja el (SHEIN, 2009), míg egyes kutatók és mérnöki szabványok a 0,005 mm-t rögzítik, mint az agyagfrakció felső mérethatárát (SHAW \& ALEXANDER, 1936; GOST 12536-79; GEE \& OR, 2002). A porfrakció felső mérethatára az előzőnél még nagyobb változatosságot mutat. A legelterjedtebb és legrégebbi mérethatár a 0,02 mm (ATTERBERG, 1912), ez volt sokáig a hazai talajtani vizsgálati módszertanban is a por/homok határ (DI GLÉRIA et al., 1957). 1938-tól vezették be az USDA módszertanba a $0,05 \mathrm{~mm}$-es por/homok mérethatárt, mely aztán fokozatosan elterjedt az egész világon (LYON et al., 1943); a legutóbbi évekig a nemzetközi szabványokban is ez szerepelt (ISO/DIS). 1947-től az Amerikai Geofizikai Unió a 0,062 mm-t fogadta el a porfrakció felső mérethatárának (AGU, 1947); a jelenlegi ISO módszer pedig egy ehhez hasonló értéket $(0,063 \mathrm{~mm})$ rögzít, mint por/homok mérethatárt. A homokfrakció felső határa általában $2 \mathrm{~mm}$, ez alól kivétel az orosz klasszifikációs rendszer 1 mm-es mérethatára (SHEIN, 2009). Az „alfrakciók” felosztása még az eddigieknél is nagyobb változatosságot mutat.

A szitás-ülepítéses módszereket az 1700-as évek elejétől használták a különböző méretü talajrészecskék elválasztására tapasztalati alapon (MILLER et al., 1988). Szitával a homokfrakciót (vagy annak egy részét) különítjük el az ülepítés megkezdése előtt. A jelenleg érvényben lévő ISO módszer a 0,063 mm feletti, az ISO/DIS módszer a 0,05 mm feletti teljes homokfrakciót, míg az MSZ módszer csak a 0,25 mm feletti durva homok frakciót választja le szitálással. Az ülepítéses módszerek elméleti alapjául szolgáló Stokes-törvény 1904-től ismert (HALL, 1904). 
A mérések során az ülepedési sebességek kiszámításához ismerni kell az ülepedő talaj sűrüségét (MATTHEWS, 1991). Az MSZ módszer előírja a talajok piknométerrel, vizes közegben történő sürüség meghatározását (látszólagos sủrüség), azonban a tényleges gyakorlat az, hogy a sürüség mérése vagy a lényegesen egyszerübb mérőlombikos eljárással történik (FILEP, 1995), vagy az ülepítés során a talajok átlagsürüségével $\left(2,65 \mathrm{~g} \mathrm{~cm}^{-3}\right)$ számolnak. Az ISO/DIS és ISO módszer is a talajok átlagsürüségét veszi alapul. Befolyásolhatja az ülepedési sebességet az ülepedő szuszpenziók hőmérséklete is. Ezt egyes eljárások a szuszpenziókat tartalmazó ülepítő hengerek termosztálásával oldják meg, de sokkal gyakoribb - az MSZ, illetve az ISO/DIS és ISO módszereknél is ez a megoldás - a hőmérsékleti korrekciós táblázatok alkalmazása. A különböző mérési módszerek kiemelten a lézerdiffrakción alapuló mérési eljárások - szemcsefrakció elkülönítésre vonatkozó tapasztalatait előző közleményünkben foglaltuk össze (MAKÓ et al., 2017b).

A MÖ mérési eredmények értékelése során gyakran használunk ún. háromszögdiagramokat, hogy a táblázatos formában kapott mérési eredményeket „átfordítsuk” fizikai féleség kategóriákra. A háromszögdiagramok (az azokban alkalmazott fizikai féleség kategóriák száma, illetve agyag-, por- és homokszázalékban megadott „tartomány-határa”) országonként és szakterületenként szintén különbözőek (MOEYS, 2014), de legáltalánosabban elterjedtnek az ún. USDA textúra-diagram tekinthető (USDA, 1993).

A különféle MÖ meghatározási eljárásokat megismerve felmerül a kérdés, hogy mely mérési, illetve előkészítési módszer tekinthetők szakmai szempontból leginkább elfogadhatónak. A kérdés megválaszolásához hozzásegíthet bennünket, ha a mechanikai összetétel mérési eredményeket összevetjük egymással, illetve olyan egyéb talajfizikai paraméterekkel (pl. fajlagos felület, képlékenységi mutatók, vízgőzadszorpció stb.), melyek kapcsolata tudományosan igazolt a MÖ eredményekkel (MAKÓ et al., 2002; MAKÓ \& HERNÁDI, 2010). Jelen közleményünkben egy, az ország főbb talajtípusait reprezentáló talajfizikai adatbázison hasonlítjuk össze az MSZ és az ISO/DIS módszerrel meghatározott MÖ vizsgálati eredményeket, vizsgáljuk kapcsolatukat egyéb talajfizikai tulajdonságokkal, illetve bemutatjuk a két módszer mérési eredményei közti konverzió egy lehetőségét.

\section{Anyag és módszer}

\section{A talajok leírása}

A MÖ vizsgálatok adatbázisának talajmintái 69 talajszelvény 339 különböző genetikai szintjeiből származnak (1. ábra). A hazai osztályozás szerint tekintve, a vizsgálatba bevont szelvények csaknem kétharmada erdötalaj, közel azonos arányban találhatók mezőségi illetve réti, vagy öntéstalajok (14 és 11\%), 9\% a vázvagy kőzethatású talajok aránya, két szelvény pedig szikes (Karcag). A feltárt 44 erdőtalaj szelvény zöme Zala-megyében, illetve Keszthely környékén található, ezek elsősorban Ramann-féle, illetve agyagbemosódásos barna erdőtalajok. 
Pszeudoglejes barna erdőtalajt Magyarszombatfán tártunk fel. A vizsgált mezőségi szelvények többsége karbonátos (két szelvény kivételével), jellemzően vályog, agyagos vályog fizikai féleségü. Réti és öntéstalajok zömében a Tiszántúlon, a Mezőföldön, illetve a Dráva mentén kerültek feltárásra, nagy részük nehéz mechanikai összetételü, háromnegyedük karbonátos. Humuszkarbonát, futóhomok és rendzina talajok egy-két szelvénnyel képviseltetik magukat az adatbázisban.

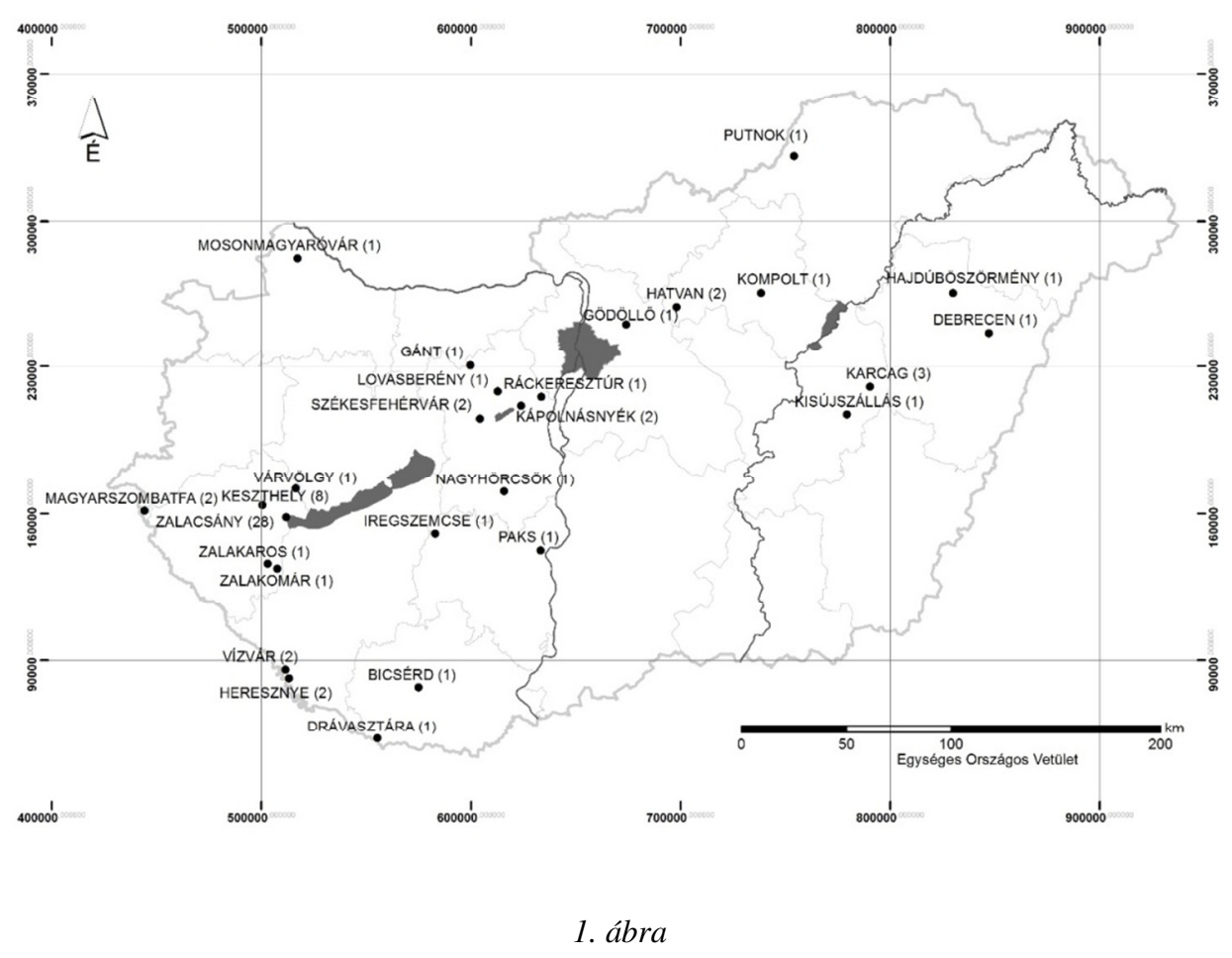

A mechanikai összetétel adatbázis talajmintáinak származási helye (zárójelben a feltárt szelvények száma)

A talajminták alapvizsgálatait a hazai talajvizsgálati módszertan szerint végeztük el (MSZ-08-0206-2-78; Buzás, 1988; 1993). Az adatbázisból - az eredmények megbízhatóságának növelése céljából - kiszürtük az extrém kicsi és nagy $\mathrm{pH}$-jú $\left(\mathrm{pH}_{\mathrm{DV}} \leq 5,5, \mathrm{pH}_{\mathrm{DV}} \geqq 9,5\right)$, a nagy humusztartalmú (humusz $\% \geqq 5$ ) és nagy mésztartalmú $(\mathrm{CaCO} 3 \% \geqq 35$ ) talajmintákat (ez összesen 3\%-ot jelent). Későbbi következtetéseink tehát azokra a talajmintákra érvényesek, melyek az előbbi tulajdonságaik alapján a megadott értelmezési tartományba esnek. 
A mechanikai összetétel vizsgálatok

Összehasonlító MÖ vizsgálatokat végeztünk az MSZ (MSZ-08-0205-78) és az ISO/DIS (ISO/DIS 11277:1994) módszerekkel. Választásunk azért esett a régebbi ISO/DIS szabványra az újabb ISO (ISO 11277:2009(E)) szabvány helyett, mert

a., a két módszertan közt nincs lényeges elvi különbség;

b., az ISO módszer az ISO/DIS módszerhez képest olyan módszertani egyszerüsítéseket tartalmaz, ami ugyan könnyebbé teszi a munkát, de megítélésünk szerint - csökkenti a mérések pontosságát;

c., az ISO/DIS módszer az ISO módszerrel ellentétben a 0,05 mm-es por/homok mérethatárral számol, ami lényegesen egyszerüsíti az MSZ módszerrel történő összehasonlítást.

\section{1. táblázat}

A mechanikai összetétel adatbázis főbb talajtani jellemzői

\begin{tabular}{|c|c|c|c|c|}
\hline Tulajdonság (1) & Átlag (2) & Szórás (3) & Minimum & Maximum \\
\hline ISO_agyag $^{\mathrm{a}}(\mathrm{m} \%)$ & 31,63 & 11,41 & 4,01 & 72,90 \\
\hline ISO_por $^{\mathrm{b}}(\mathrm{m} \%)$ & 43,54 & 13,48 & 5,04 & 79,39 \\
\hline ISO_homok $^{\mathrm{c}}(\mathrm{m} \%)$ & 24,84 & 18,83 & 0,71 & 89,71 \\
\hline MSZ_agyaga (m\%) & 24,58 & 12,13 & 1,90 & 56,80 \\
\hline MSZ_por ${ }^{\mathrm{b}}(\mathrm{m} \%)$ & 44,00 & 13,53 & 6,20 & 78,50 \\
\hline $\operatorname{MSZ} \operatorname{homok}^{\mathrm{c}}(\mathrm{m} \%)$ & 30,94 & 19,55 & 1,93 & 83,93 \\
\hline Arany-féle kötöttség & 45 & 12 & 19 & 96 \\
\hline $\mathrm{pH}\left(\mathrm{H}_{2} \mathrm{O}\right)$ & 7,5 & 0,9 & 4,4 & 9,4 \\
\hline humusz (m\%) & 1,7 & 1,5 & 0,0 & 10,6 \\
\hline $\mathrm{CaCO}_{3}(\mathrm{~m} \%)$ & 6,9 & 9,5 & 0.0 & 48,2 \\
\hline
\end{tabular}

agyag, agyag frakció $(<0,002 \mathrm{~mm}) ;{ }^{\text {b }}$ por, por frakció $(0,002-0,05 \mathrm{~mm}) ;{ }^{\mathrm{c} h o m o k}$, homok frakció (0,05-2,0 mm), nemzetközi (ISO/DIS) ill. magyar szabvány (MSZ) szerinti elökészítéssel $(\mathrm{N}=339)$

Az MSZ módszernél a talajok mérőlombikos eljárással meghatározott sürüség értékei alapján számoltuk a részecskék ülepedési sebességét, illetve a pipettázási időket és mélységeket. Az ISO/DIS szabvány esetében - a módszerhez igazodóan az átlagsürüség $\left(2,65 \mathrm{~g} \mathrm{~cm}^{-3}\right)$ értékek szerint dolgoztunk. A méréseket szobahőmérsékleten végeztük, mindkét módszernél hőmérsékleti korrekciókkal számolva, a Pannon Egyetem Georgikon Karának Növénytermesztéstani és Talajtani Tanszékén.

Az ISO/DIS módszer nem írja le egyértelmüen, hogy mely esetben kell elvégezni a humuszanyagok roncsolásán túl a mész és a vas-(oxi)hidroxidok 
eltávolítását, ezt a vizsgálatot végző döntésére bízza, ami nagyfokú bizonytalanságot okoz a mérési eredmények összehasonlíthatóságában. Ebből a megfontolásból a teljes mintaanyagon elvégeztük mindhárom ragasztóanyag eltávolítását a javasolt módszertan szerint. A kezelések során alkalmazott reagensek mennyiségét - az ISO/DIS szabványnak megfelelően - a humusz-, a mész- és a vas(oxi)hidroxid tartalomhoz igazítottuk.

Az ISO/DIS módszer esetében a mérési eredményeket vagy az összes talaj százalékában adhatjuk meg (ilyenkor a százalékos agyag-, por- és iszapfrakció, illetve humusz és mésztartalom együttesen adja a 100\%-ot), vagy a diszpergált talaj százalékában (ebben az esetben a mért agyag-, por és homoktartalom összege a $100 \%)$. A számolások során a mérés kezdetekor bemért talaj mennyisége és a mért agyag-, por- és homokfrakció, valamint az alapvizsgálatokból származó humusz- és mésztartalom összes mennyisége közti különbséget „előkészítési veszteségként” határoztuk meg (az a kioldott vagy a centrifugálás után kolloidális formában lebegő állapotban maradt talajásvány mennyiség, mely az előkészítések során elöntésre került; a vizsgált talajok esetében maximálisan 25,3 \% volt). Ezt a talajmennyiséget egyezményesen az agyagfrakció részeként értelmeztük és korrekcióként hozzáadtuk a ténylegesen mért agyagtartalomhoz. (Az előkészítési veszteség „kezelésére” egyébként nem találtunk utalást az ISO/DIS szabványban, és a vonatkozó szakirodalmakban is csak elvétve (pl. KUBOTA, 1972).) Mind az összes talaj százalékában, mind pedig a diszpergált talaj százalékában megadott MÖ eredmények az ily módon korrigált agyag mennyiségeket tartalmazzák. Megfontolandó, hogy melyik eredményközlés agyag-, por- és homokfrakció adatai vethetők össze jobban az MSZ módszer adataival. Elözetes korrelációs vizsgálataink és szakmai megfontolások (pl. hogy a három szemcsefrakció összege $100 \%$ legyen) után arra a következtetésre jutottunk, hogy az ISO/DIS módszer eredményeiből a diszpergált talaj százalékában megadott frakciókat választjuk ki az összehasonlító vizsgálatok céljára.

Az MSZ és ISO módszerekkel végzett MÖ vizsgálatok eredményeit és a talajtani alapvizsgálati adatokat tartalmazó talajfizikai adatbázis lehetőséget nyújtott arra, hogy megvizsgáljuk az MSZ módszer eredményeinek ISO/DIS módszerü adatokká történő konverziójának esélyét és a kialakított becslési eljárás megbízhatóságát. Olyan konverziós módszer kidolgozására törekedtünk, mely az MSZ módszer eredményei mellett a talajok alapvizsgálati adatait is felhasználja a becslés során.

\section{Statisztikai vizsgálatok}

A konverziós módszer kidolgozásához az eredeti adatbázist 2/3 - 1/3 arányban „becslő” és „,teszt” részadatbázisokká bontottuk. A „becslő” adatállományon történt a konverziós egyenletek kidolgozása, míg a „teszt” adatállomány a módszer validálására szolgált. Az előzetes adatelemzések után lineáris regressziós módszerrel (SPSS Statistics, Regression, Automatic linear modeling (LINEAR), Standard model, Best subsets, AICC information criterion, 10 component models) vizsgáltuk a talajok MSZ módszer szerinti százalékos agyag-, por- és 
homoktartalma, a humusz- és mésztartalma, illetve a desztillált vizes szuszpenzióban mért pH-ja, (független változók) és az ISO/DIS módszer szerinti százalékos agyag-, por- és homoktartalma (függő változók) közti kapcsolatot. Elözetes tapasztalataink alapján a becslő egyenletekbe bevontuk a független változók transzformált (négyzetes, logaritmusos és reciprok és szorzat) alakjait is (TóTH et al., 2015; MAKó et al., 2017a).

A fenti módon kialakított pedotranszfer függvények (PTF) pontosságát a determinációs koefficiens $\left(\mathrm{R}^{2}\right)$ és az átlagos négyzetes eltérés négyzetgyöke (RMSE) $(\mathrm{m} \%)$ (1. egyenlet) alapján vizsgáltuk:

$$
R M S E=\sqrt{\frac{1}{N} \sum_{i=1}^{N}\left(y_{i}-\hat{y}_{i}\right)^{2}}
$$

ahol $\mathrm{y}_{\mathrm{i}}$ az ISO/DIS módszerrel mért agyag-, por- vagy homoktartalom, $\hat{\mathrm{y}}_{\mathrm{i}} \mathrm{a}$ becsült agyag-, por- vagy homoktartalom, $\mathrm{N}$ a mintaszám.

A becslések megbízhatóságát a „teszt” adatállományon vizsgáltuk, a fenti statisztikai mutatókkal.

A talajadatbázis mintáit ezután az USDA háromszögdiagram alapján fizikai féleség szerint kategorizáltuk az R program (R Core Team, 2013) 'soiltexture' programcsomagjának (MOEYS, 2014) algoritmusai alapján. Az MSZ és ISO/DIS módszerekkel mért, illetve a kidolgozott PTF-ekkel becsült agyag-, por- és homoktartalmak alapján meghatározott fizikai féleség kategóriákat összehasonlítottuk egymással, vizsgáltuk azok megegyezőségét („,megegyezőségi mátrix" vizsgálatok). Szintén a fenti programcsomag alkalmazásával megrajzoltuk az USDA háromszögdiagramokat a mért és becsült MÖ adatok, fizikai féleség kategóriák vizuális összehasonlítása céljából, majd a textúra háromszögdiagramok MÖ adatait az agyag - por - homok százalék koordinátákból X - Y koordinátarendszerbe konvertáltuk (MOEYS, 2009). Kiszámoltuk a kétdimenziós Kernel sűrüségfüggvényt ('TT.kde2d()'), majd egy visszakonvertálás után ábrázoltuk a háromszögdiagramokon a mért és a becsült MÖ adatok adatszerkezetének szemléltetése végett (MoEYs, 2014). A Kernel sủrüségbecslés széles körben elterjedt módszer a megfigyelések sủrüségének kódolására és az adatok kiterjedésének térbeli ábrázolására (SIMONOFF, 1996; VENABLES \& RIPLEY, 2002).

A MÖ adatok összehasonlítása bonyolult feladat, hiszen ezek a mérési eredmények kompozit adatok, melyeknek az összege 100\%. Ez azt jelenti, hogy az egyik frakció növekedése a többi frakció csökkenését eredményezi, vagyis az egyes frakciók eloszlása nem független egymástól. Ennek a problémának egy megoldási lehetöségeként a 'soiltexture' R csomag ('TT.css2xy()') segítségével az USDA háromszögdiagramokon ábrázolt (a két módszerrel mért és a becsült) MÖ adatokat X-Y koordinátarendszerbe konvertáltuk, majd kiszámoltuk az MSZ és az ISO/DIS módszerrel mért, illetve a PTF-ek segítségével becsült és az ISO/DIS módszerrel mért pontok távolságát (MOEYS, 2009). Ezt a dimenzió nélküli változót használtuk ezután a mért és becsült eredmények összehasonlítására, a becslési módszer 
hatékonyságának jellemzésére. Az egyes frakciók páronkénti összehasonlítására a T-próbát alkalmaztuk (SPSS Statistics, Paired-Samples T test). Megvizsgáltuk továbbá, hogy mely MÖ vizsgálati módszer eredményei korrelálnak jobban a két leggyakrabban használt közvetett fizikai féleség meghatározási módszer (a talajok Arany-féle kötöttsége és higroszkópossága) vizsgálati eredményeivel.

\section{Eredmények és következtetések}

A vizsgálatokba vont talajok mind talajgenetikailag, mind pedig fizikai és kémiai tulajdonságaikban nagyfokú heterogenitást mutatnak (1. táblázat). A 2/a. ábra boxplot és a $2 / b$. ábra pontdiagramjain összehasonlítottuk az MSZ és ISO/DIS módszerrel meghatározott MÖ vizsgálatok eredményeit. Az agyag- ( $<0,002 \mathrm{~mm}$ ), por- $(0,002-0,05 \mathrm{~mm})$ és homokfrakció ( > 0,05 mm) átlagos értéke 24,6 - 44,5 30,9\% volt az MSZ módszer szerint, míg az ISO/DIS módszer alapján 31,6 - 43,5 24,9\% mértünk. Látható, hogy az ISO/DIS szabványnál alkalmazott elökezelések némiképp megváltoztatták a frakciók arányait: az agyagtartalom szignifikánsan nőtt, míg a portartalom kisebb mértékben, a homoktartalom nagyobb mértékben igazolhatóan csökkent. Ennek oka föként az volt, hogy az MSZ módszernél az elemi részecskék a talajminták egy részénél „pszeudofrakciók” formájában mikroaggregátumként ülepednek a mérések során a Na-pirofoszfátos kémiai és a 610 órás fizikai (rázatás) diszpergálás ellenére. Az agyagfrakció egy része ilyenkor a mikroaggregátumokban organominerális kötésben marad és a por- vagy homokfrakció részeként mérjük vissza (FEDOTOV et al., 2007). Egy másik lehetséges ok a nagy karbonát-tartalmú talajoknál a por- és homokfrakcióba eső karbonát darabkáknak (esetleges konkréciók vagy kőzettörmelékek talajdarálás utáni törmelékeinek) a sósavas elökezelés során történő kioldódása lehet.

A $2 / b$. ábrán az is jól látható, hogy a talajok tulajdonságaitól függően eltérő mértékben változtak meg a frakciók arányai: néhány esetben az ISO/DIS módszer alkalmazása - az általános trenddel szemben - az agyagtartalom csökkenését, illetve a homoktartalom növekedését eredményezte és az esetek egy részében nem volt megfigyelhető a frakciók arányainak megváltozása. A portartalmak esetében volt a legnagyobb a szórás: közel megegyező esetben történt portartalom csökkenés és növekedés. Az ISO/DIS módszer esetében az MSZ módszer eredményeihez viszonyított agyagtartalom csökkenések nagy valószínűséggel módszertani okokra vezethetők vissza. Az előkészítések során az agyagfrakciót alkotó ásványok egy része degradálódott (vas-(oxi)hidroxidok kioldódása, agyagásványok átalakulása), „előkészítési veszteségként” elöntésre került, amelyet az eredmények kiszámításakor valószínúleg nem a megfelelö mértékben vettünk figyelembe (BALÁzS et al., 2011). Az ISO/DIS homokfrakció MSZ módszer eredményeihez viszonyított esetenkénti növekedésének egyik elképzelhető oka lehet a módszertől függően különböző mennyiségü vízben oldhatatlan Ca-hexametafoszfát, illetve Capirofoszfát részecskék képződése a diszpergálás során (KACHINSKY, 1965). A porfrakciók arányának nagy változatossága pedig valószínúleg azzal magyarázható, hogy - a talajokban eredetileg meglévő kötőanyagok mennyiségétől és a talajok 
szerkezetességétől függő mértékben - az előkészítések hatására egyrészt a talajok nagyobb, a homokfrakcióba eső aggregátumainak szétesésével megnőhetett nemcsak az agyag, hanem a por mérettartományba eső részecskék mennyisége is, másrészt a por mérettartományba eső mikroaggregátumok is széteshettek kisebb alkotóelemekre, miáltal le is csökkenhetett a porfrakció mennyisége.

a.

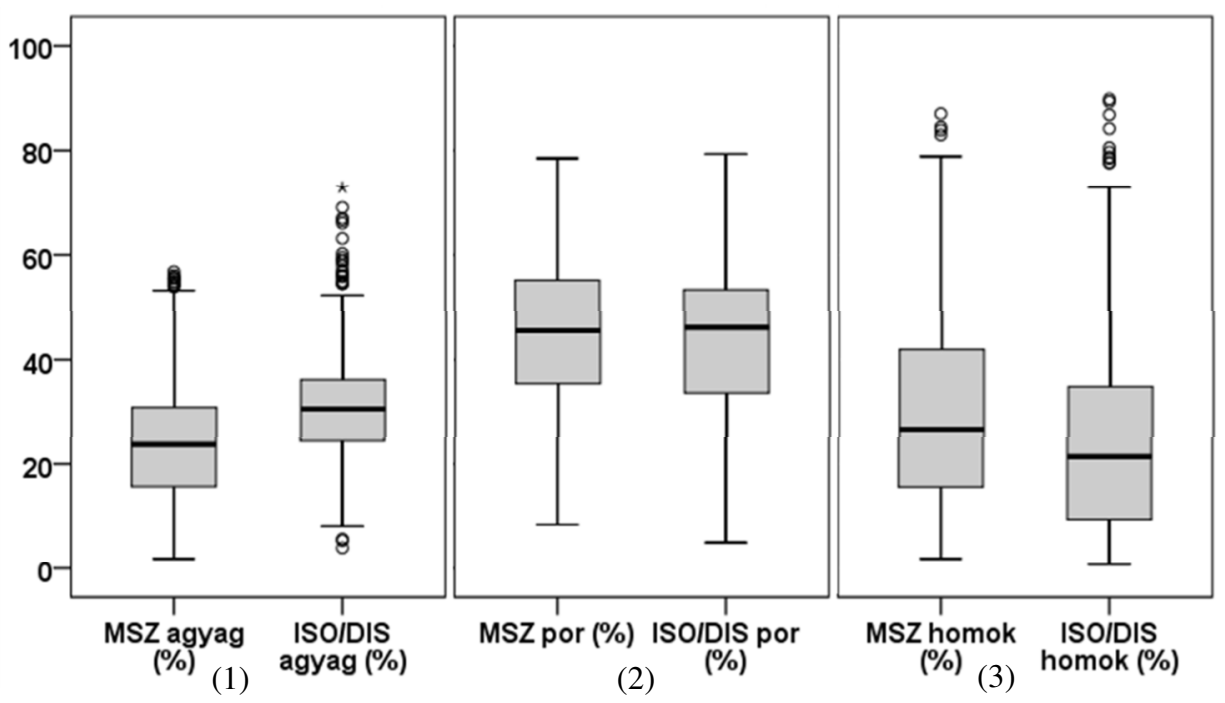

b.

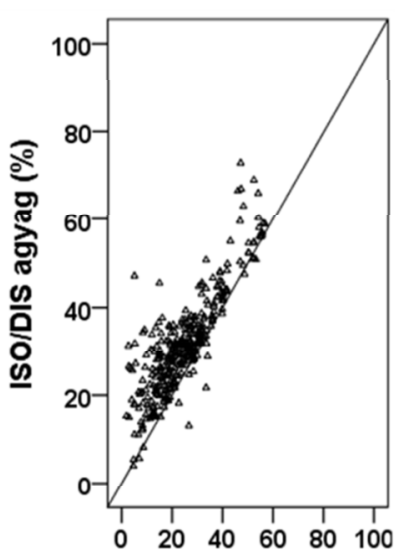

(1) MSZ agyag (\%)

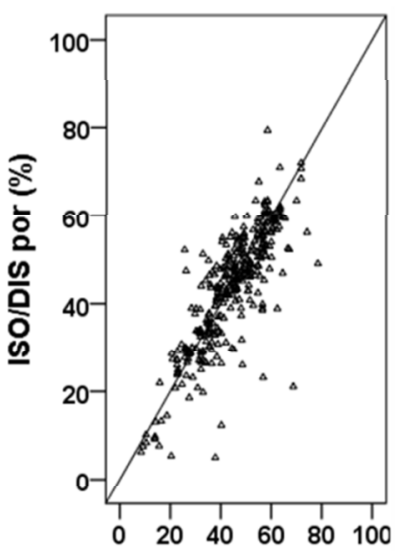

(2) MSZ por (\%)

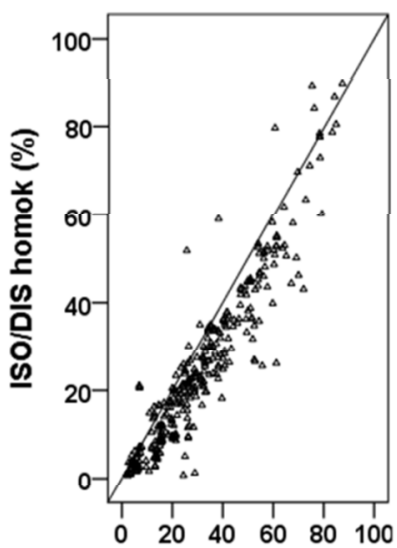

(3) MSZ homok (\%)

2. ábra

A két módszerrel meghatározott mechanikai összetétel frakciók összehasonlítása 
A továbbiakban megvizsgáltuk, hogy mely MÖ vizsgálati módszer eredményei tekinthetők szakmai szempontból pontosabbaknak. Ismert, hogy az Arany-féle kötöttségi számot (a képlékenység felső határát), illetve a Sík-féle higroszkóposságot (monomolekuláris rétegü vízgőzadszorpciót) elsősorban a talajok agyagtartalma határozza meg. A 3. ábrán bemutatott eredmények szerint mind a talajok Arany-féle kötöttségi számával, mind pedig a higroszkópossági értékekkel szorosabb kapcsolatot mutatott az ISO/DIS módszerrel mért $\left(\mathrm{R}^{2}=0,56\right.$ és 0,85$)$, mint az MSZ módszerrel mért $\left(\mathrm{R}^{2}=0,45\right.$ és 0,65$)$ agyagtartalom, így az eredmények várakozásainknak megfelelően igazolták az ISO/DIS vizsgálatok nagyobb pontosságát. (A szakirodalomból ismert, hogy mind a kötöttségi szám, mind pedig a higroszkóposság az agyagtartalmon kívül számos egyéb talajtulajdonság függvénye. Ezért az összefüggések mindkét módszer esetében valójában jónak tekinthetők (DI GLÉRIA et al., 1957).) A fentiekből az következik, hogy amennyiben a MÖ mérések eredményeit kutatási céllal, nagyobb pontossággal kívánjuk meghatározni, célszerủ a jóval idő- és eszközigényesebb ISO/DIS módszert alkalmaznunk. Szintén ez a módszer javasolható nemzetközi összehasonlító munkák során is (pl. az egyes talajok nemzetközi talajosztályozási rendszerekbe történő besorolásakor).
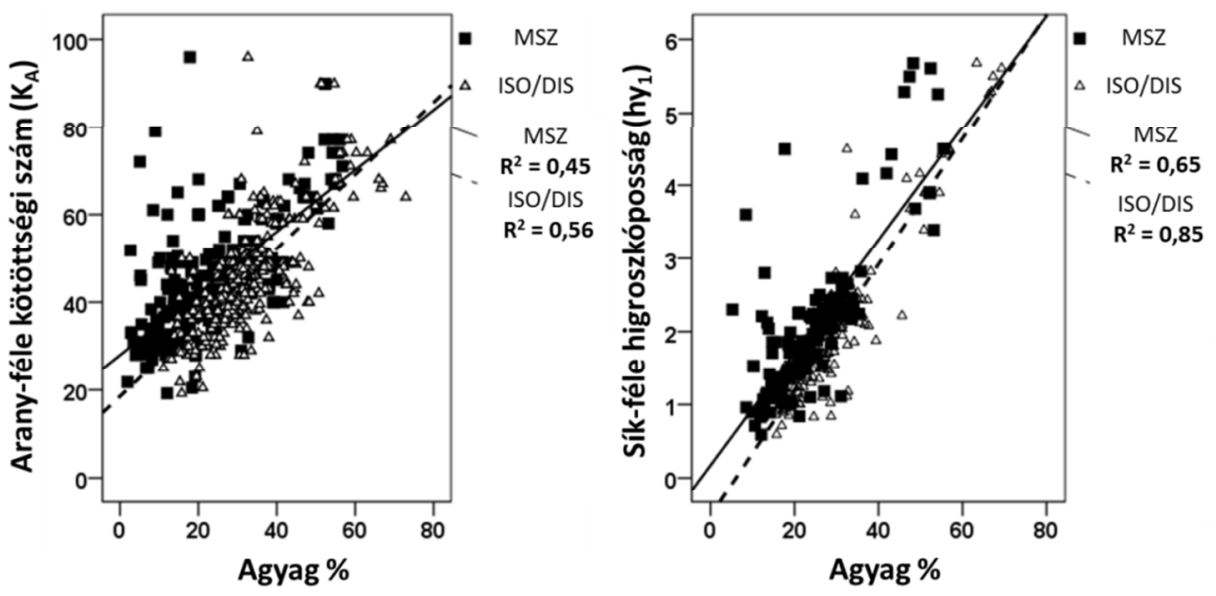

3. ábra

A talajok kétféle módszerrel mért agyagtartalmának kapcsolata az Arany-féle kötöttségi számmal és a Sík-féle higroszkópossággal

Amikor nem áll rendelkezésre laboratóriumi kapacitás az ISO/DIS szabvány szerinti mérésekre, vagy régebbi, MSZ módszer szerinti vizsgálati eredményeket kell összevetnünk nemzetközi mérési adatokkal, akkor célszerü lenne a két módszer eredményeit egymásnak megfeleltetni valamilyen módon. Ezért a továbbiakban megvizsgáltuk az MSZ módszertan szerint mért MÖ adatok ISO/DIS adatokká történő konverziójának lehetőségét. Vizsgálataink egyértelmüvé tették, hogy az 
MSZ és az ISO/DIS módszertan eredményei közti különbség oka nagyrészt az, hogy az MSZ módszertannal csupán a szerkezeti elemek részleges dezaggregációját tudjuk elérni, az elemi részecskék egy része mikroaggregátum formában marad. Feltételeztük tehát, hogy a talajok szerkezetstabilitásának kialakításában szerepet játszó talajkomponensek mennyisége (humusz- és mésztartalom), illetve a szerkezetstabilitásra szintén ható talaj $\mathrm{pH}$ eredményesen bevonható független változóként a kidolgozandó becslőegyenletekbe. Ezek a talajtulajdonságok alapvizsgálati paraméterekként általában rendelkezésre állnak, szemben a talajok nehézkesebben mérhető vas-(oxi)hidroxid tartalmával, vagy a kicserélhető $\mathrm{Na}^{+}$ tartalommal, mely talajtulajdonságok egyébként szintén befolyásolhatják az aggregátum-stabilitást. A 2. táblázat tartalmazza az ISO/DIS és az MSZ módszerrel mért MÖ frakciók közötti összefüggést leíró egyenleteket. A statisztikai vizsgálatok alátámasztják, hogy a két módszertan közötti konverziós függvényekben a MÖ-t jellemző frakciók mennyisége mellett valóban fontos független változó a talaj humusz- és mésztartalma, továbbá a vizes pH-ja.

\section{2. táblázat}

Az ISO/DIS agyag-, por és homokfrakciók becslésére javasolt pedotranszfer függvények

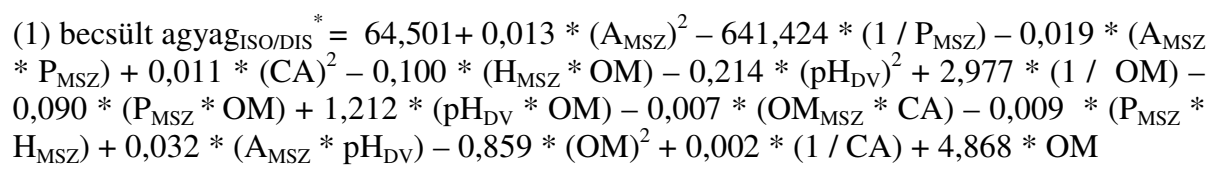

(2) becsült homok $\mathrm{ISO} / \mathrm{DIS}=-3,828+475,114 *\left(1 / \mathrm{P}_{\mathrm{MSZ}}\right)+0,009 *\left(\mathrm{H}_{\mathrm{MSZ}} * \mathrm{CA}\right)-0,008 *$ $(\mathrm{CA})^{2}+0,374 * \mathrm{H}_{\mathrm{MSZ}}+0,005 *\left(\mathrm{~A}_{\mathrm{MSZ}} * \mathrm{H}_{\mathrm{MSZ}}\right)-0,002 *\left(\mathrm{~A}_{\mathrm{MSZ}}\right)^{2}-0,017 *\left(\mathrm{H}_{\mathrm{MSZ}} * \mathrm{OM}\right)$ $+0,003 *\left(\mathrm{H}_{\mathrm{MSZ}}\right)^{2}$

(3) becsült por $_{\text {ISO/DIS }}=100-$ (becsült agyag ${ }_{\text {ISO/DIS }}+$ becsült homok $_{\text {ISO/DIS }}$ )

" $\mathrm{A}_{\mathrm{MSZ}}, \mathrm{P}_{\mathrm{MSZ}}, \mathrm{H}_{\mathrm{MSZ}}$ : az MSZ módszerrel mért MÖ (agyag-, por-, homok-) frakciók (< 0,002 mm, 0,002-0,05 mm, > 0,05 mm) (\%); OM: humusz tartalom (\%); CA: $\mathrm{CaCO}_{3}$ tartalom (\%); $\mathrm{pH}_{\mathrm{DV}}$ : desztillált vizes szuszpenzióban mért $\mathrm{pH}$

A 4. ábrán láthatók a konverziós egyenletek hatékonyságát jellemző RMSE és $\mathrm{R}^{2}$ értékek a becslő és teszt adatbázis részeken végzett vizsgálatok alapján. Az ábra alapján elmondható, hogy a pedotranszfer függvények alkalmazásával jelentősen sikerült egymáshoz közelíteni a mért és a becsült ISO/DIS frakciók mennyiségeit, általában nagymértékben csökkent az átlagos eltérés (RMSE). A becslő adatbázis esetében, az RMSE értékek az agyagfrakciónál 9,75-ről 4,19\%-ra, a porfrakciónál 7,57-ről 6,19\%-ra és a homokfrakciónál 9,18-ról 5,14\%-ra csökkentek. A teszt adatbázis esetében az agyagfrakciónál 9,56-röl 6,81\%-ra, a homokfrakciónál 9,88ról 5,88\%-ra csökkentek az RMSE értékek. A teszt adatbázis porfrakciójánál kisebb mértékü (1,44\%-os) RMSE növekedést tapasztaltunk, ami egyrészt a porfrakció számítási módjából következik (hiszen ennél a frakciónál adódnak össze az agyagés homokfrakciók becslési hibái), másrészt azt is mutatja, hogy a porfrakció 
becslése a legkevésbé megbízható. Az $\mathrm{R}^{2}$ értékek esetében a becslő adatbázison egyöntetüen kismértékủ növekedés tapasztalható (agyag-, por és homokfrakciónál 0,15; 0,07 és 0,05 értékkel nőtt), míg a teszt adatbázison az agyag- és portartalomnál a regressziós kapcsolat kismértékü $\left(R^{2}: 0,06\right.$ és 0,12$)$ csökkenését, a homoktartalomnál kismértékü $\left(\mathrm{R}^{2}: 0,05\right)$ növekedését tapasztaltuk. Ezek az eredmények szintén alátámasztják azt a fenti tapasztalatunkat, miszerint a javasolt becslési módszer szerint a portartalom számítása kevésbé megbízható. (A becslési eljárás kidolgozása során - a fentiekhez leírtakhoz hasonlóan -megkíséreltük olyan pedotranszfer függvények kidolgozását is, amikor az ISO/DIS agyag- és portartalmat, vagy a por- és homoktartalmat becsültük az MSZ frakciók és az alapvizsgálati paraméterek ismeretében, és a harmadik homok- vagy agyagfrakciót számítottuk az összegek 100\%-ból történő kivonásával, azonban ezek a változatok a bemutatott konverziós függvényeknél rendre gyengébb hatékonyságot mutattak.)

Meg kell jegyeznünk ugyanakkor - az ide vonatkozó kutatási tapasztalatok alapján -, hogy az $\mathrm{R}^{2}$ értékek kevésbé informatívak a MÖ frakció becslések megbízhatóságáról, hiszen nem tükrözik megfelelően a frakciók „alul-,, vagy „felülbecslését” (LiN, 1989; LIN et al., 2002; FISHER et al., 2017; MAKó et al., 2017a).

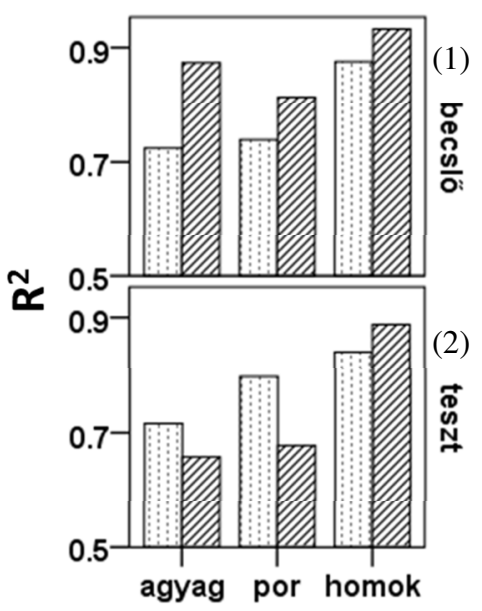

(3)

(4)

(5)
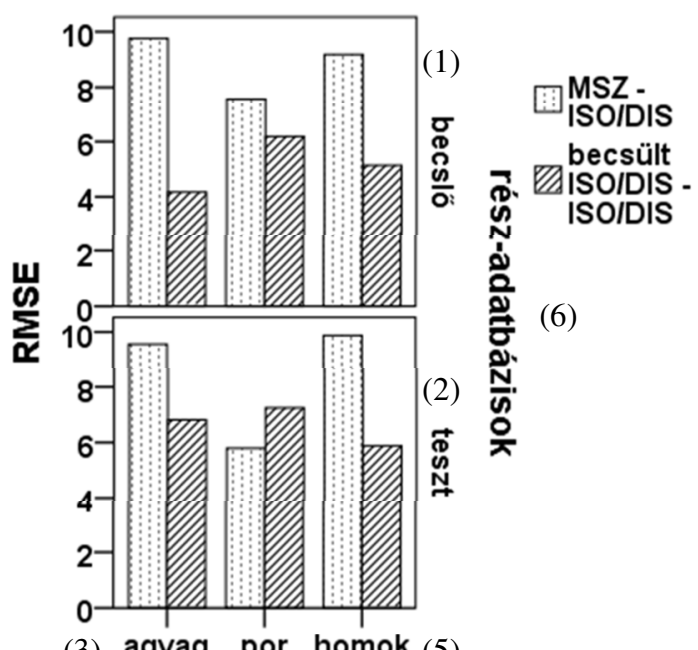

(3) agyag $_{4)}$ por homok (5)

(7) Mechanikai összetétel frakciók

4. ábra

A javasolt konverziós egyenletek becslési pontosságának és megbízhatóságának bemutatása $\left(\mathrm{R}^{2}\right.$ : a mért MSZ és ISO/DIS frakciók, illetve az MSZ frakciókból becsült és mért ISO/DIS frakciók közti determinációs koefficiens; RMSE: a mért MSZ és ISO/DIS frakciók, illetve az MSZ frakciókból becsült és mért ISO/DIS frakciók közti átlagos négyzetes eltérés négyzetgyöke $(\mathrm{m} \%))$ 
Egy másik lehetőség a konverziós becslő egyenletek kiértékelésére az, amikor az agyag-, por- és homokfrakciókat összevonva együtt értékeljük úgy, hogy a talajokat elhelyezzük az USDA háromszögdiagramon és vizsgáljuk a fizikai féleség kategóriák egymásnak való megfeleltethetőségét. Az 5. ábrán az MSZ és ISO/DIS módszerekkel mért, illetve a konverziós egyenletekkel MSZ frakciókból számított ISO/DIS MÖ adatokat helyeztük el háromszögdiagramokon. A diagramok alapján megállapítható, hogy a mért adatpontok térbeli szerkezete az MSZ és az ISO/DIS módszerek esetében meglehetősen eltérő. Az MSZ módszer szerint a legtöbb talaj a vályog (77 db), az iszapos vályog (77 db) és a homokos vályog (48 db) fizikai féleség kategóriába sorolható, míg az ISO/DIS mérési pontok zöme az iszapos agyagos vályog (93 db), az agyagos vályog (72 db) és a vályog (54 db) kategóriába oszthatók. A becsült ISO/DIS MÖ adatok szerkezete közelít a mért ISO/DIS adatszerkezethez, bár annál kicsit koncentráltabb: az iszapos agyagos vályog (104 $\mathrm{db})$, az agyagos vályog $(70 \mathrm{db})$ és a vályog $(54 \mathrm{db})$ fizikai féleség kategóriák az uralkodóak itt is. Elmondható, hogy a két módszerrel mért MÖ adatok alapján osztályozott fizikai féleség kategóriák egymással 40,1\%-os egyezést mutattak, míg a mért és MSZ MÖ-ből konverziós egyenletekkel becsült ISO/DIS adatok alapján megállapított fizikai féleség kategóriák egyezősége 66,7\%-os volt.

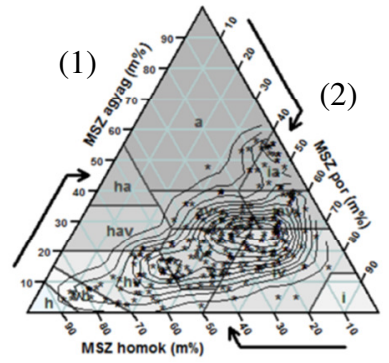

(3)

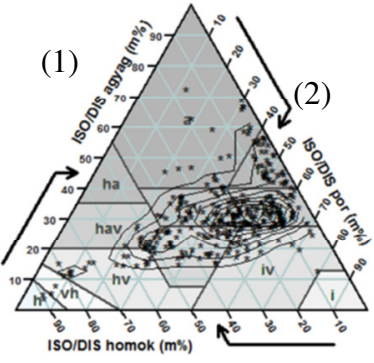

(3)

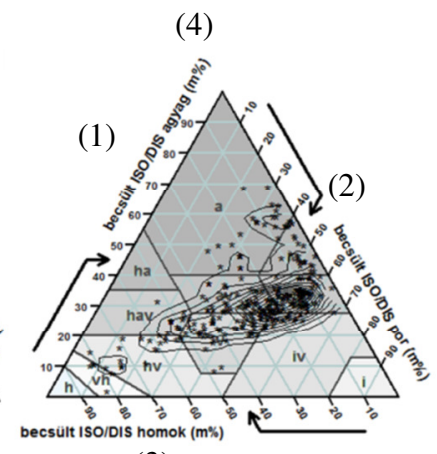

(3)

5. ábra

A különféle módszerekkel mért és a konverziós egyenletekkel becsült mechanikai összetétel eredmények összehasonlítása USDA háromszögdiagramokon, a Kernel sürüségfüggvény ábrázolásával

A „megegyezőségi mátrix” jól mutatja, hogy a javasolt becslési módszerrel jelentős mértékủ hasonlóság-javulás érhető el az MSZ és az ISO/DIS adatállományok közt. Ez az összehasonlító módszer azonban inkább kvalitatívnak tekinthető; nem tájékoztat arról, hogy ha különböző fizikai féleség kategóriákba sorolódnak a különböző módszerekkel mért, illetve becsült adatok, akkor az eltérés a pontpárok között mekkora. Erre a célra végeztük el a távolság számításokat, melynek eredményeit a 6. ábrán mutatjuk be. Az MSZ - ISO/DIS összehasonlításban általában nagyobb a pontpárok egymástól való távolsága (az átlagos távolság 9,0 (max. 40,3; min. 0,8), míg az MSZ-ből konverziós egyenlettel 
becsült ISO/DIS - ISO/DIS összehasonlításában 5,5 (max. 32,3; min. 0,3)). Az általunk vizsgált mintáknál tehát általánosságban elmondható, hogy - a homok textúrájú talajok kivételével - az összes fizikai féleség kategóriában a konverziós egyenletekkel jelentősen javul az MSZ és ISO/DIS módszerekkel mért eredmények egyezösége.

Végül megvizsgáltuk, hogy milyen a javasolt pedotranszfer függvény segítségével ISO/DIS adatokká átkonvertált agyagtartalmak kapcsolata az Aranyféle kötöttséggel és a Sík-féle higroszkópossággal. Megállapítható, hogy a regressziós kapcsolatok a konverzió hatására kis mértékben szintén javultak $\left(\mathrm{K}_{\mathrm{A}}-\right.$ agyag MSZ: $^{2}=0,45 ; \mathrm{K}_{\mathrm{A}}-$ agyag $_{\text {becsuilt Iso/DIs }}: \mathrm{R}^{2}=0,51 ;$ hy $_{1}-$ agyag $_{\mathrm{MSz}}: \mathrm{R}^{2}=0,65 ; \mathrm{hy}_{1}-$ agyag becsült ISO/DIS: $\mathrm{R}^{2}=0,73$ ). Ez azt mutatja, hogy ha a becslési módszer az ISO/DIS mérési módszert pontosságában nem is képes kiváltani, de használata kutatási munkákban, összehasonlító vizsgálatokban mindenképp javasolható, amennyiben csak az MSZ MÖ vizsgálatra van lehetőségünk, vagy régebben mért MSZ MÖ adatok állnak rendelkezésünkre.

a. $\Delta$ (MSZ-ISO/DIS)

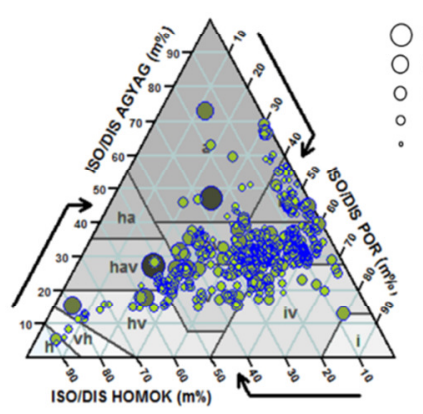

b. $\Delta$ (becsült ISO/DIS - ISO/DIS)

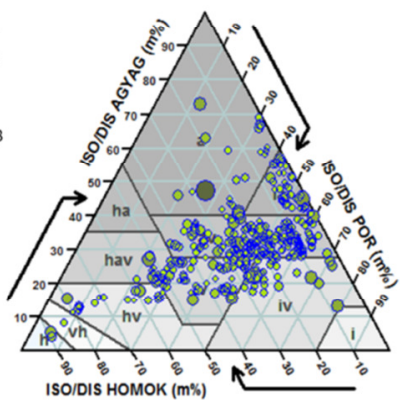

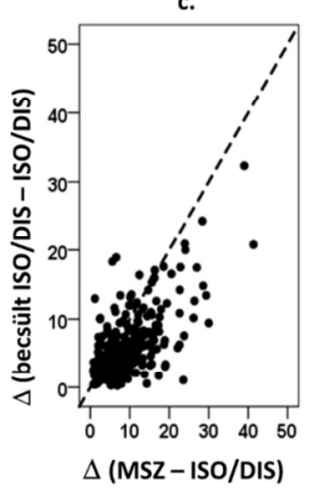

6. ábra

A MÖ pontpárok térbeli távolsága a.) az MSZ MÖ és ISO/DIS MÖ, valamint b.) MSZ MÖ-bőll pedotranszfer függvénnyel konvertált ISO/DIS és mért ISO/DIS MÖ háromszögdiagramokon ábrázolva (a nagyobb buborékok az egymástól messzebb, a kisebbek az egymáshoz közelebb elhelyezkedő pontpárokat jelölik), c.) a távolságok egymáshoz viszonyított aránya mintánként

A kutatás következö szakaszában tovább kívánjuk pontosítani mind az ISO/DIS mérési módszert, mind pedig a konverzió lehetőségét. Többek közt arra keressük a választ, hogy mivel magyarázható a mérési eljárás során tapasztalható (némely esetben igen nagymértékü) előkészítési veszteség, mennyire függ ez a talajok genetikai típusától, talajásvány-összetételétől és az egyéb talajtulajdonságoktól. Vizsgálni kívánjuk továbbá, hogy a MSZ-ISO/DIS MÖ konverzió mennyiben tehető pontosabbá, megbízhatóbbá egyéb talajtulajdonságok ismeretében, illetve hogy a talajok aggregátum-stabilitását kifejező egyéb 
mérőszámok milyen összefüggést mutatnak a két módszerrel mért MÖ eredmények eltéréseivel.

\section{Összefoglalás}

$\mathrm{Az}$ ország főbb talajtípusait reprezentáló talajfizikai adatbázison összehasonlítottuk az MSZ-08-0205-78 és az ISO/DIS 11277:1994 módszerrel meghatározott mechanikai összetétel vizsgálati eredményeket, megvizsgáltuk kapcsolatukat egyéb talajfizikai tulajdonságokkal (Arany-féle kötöttség és Sík-féle higroszkóposság), illetve bemutattuk a két módszer mérési eredményei közti konverzió egy lehetőségét.

Tapasztalataink szerint az ISO/DIS szabványnál alkalmazott elökezelések némiképp megváltoztatták a szemcsefrakciók arányait: az agyagtartalom szignifikánsan nőtt, míg a portartalom kisebb mértékben, a homoktartalom nagyobb mértékben igazolhatóan csökkent, melynek valószínüsíthetö magyarázata az, hogy az MSZ módszernél az elemi részecskék egy része mikroaggregátum formában marad. Eredményeink igazolták az ISO/DIS vizsgálatok nagyobb pontosságát: mind az Arany-féle kötöttségi számok, mind a higroszkópossági értékek szorosabb kapcsolatot mutattak az agyagtartalom ISO/DIS módszerrel mért értékeivel, mint az MSZ módszerrel mért agyagtartalom adatokkal.

$\mathrm{Az}$ általunk javasolt pedotranszfer függvények alkalmazásával a becsült ISO/DIS frakciók mennyiségeit jelentősen sikerült közelíteni a mért értékekhez. Tapasztalataink szerint a konverziós módszer az agyag- és homokfrakciók becslésére jobban, a porfrakciókéra kevésbé megbízható. Pontosságában a becslési módszer jelen formájában az ISO/DIS mérési módszert ugyan nem képes kiváltani, de használata kutatási munkákban, összehasonlító vizsgálatokban mindenképp javasolható, amennyiben csak az MSZ módszer szerinti mechanikai összetétel vizsgálatokra van lehetőség, vagy régebben mért MSZ mechanikai összetétel adatok állnak rendelkezésre.

Kulcsszavak: mechanikai összetétel, előkészítési eljárások, pedotranszfer függvények

Kutatásunk a Nemzeti Kutatási, Fejlesztési és Innovációs Hivatal támogatásával az NKFI Alapból valósult meg (KH 124765 és K119475sz. NKFI pályázatok).

\section{Irodalom}

AGU, 1947. Report of the subcommittee on sediment terminology. Transactions of American Geophysical Union. 28. 936-938.

ATterberG, A., 1912. Die mechanische Bodenanalyse und die Klassifikation der Mineralboden Schruedens. Internationale Mitteilungen für Bodenkunde. 2. 312 342. 
Balázs, R., Németh, T., MaKó, A., Kovács Kis, V. \& KereszTES, M., 2011. A mechanikai összetétel meghatározása során alkalmazott minta-előkészítés talajásványtani hatása. In: LIII. Georgikon Napok. Keszthely. 2011. szept. 29-30. 73-83.

BUZÁs I. (szerk.), 1988. Talaj- és agrokémiai vizsgálati módszerkönyv 2. A talajok fizikai-kémiai és kémiai vizsgálati módszerei. Mezőgazdasági Kiadó. Budapest. p. 243.

BUZÁs I. (szerk.), 1993. Talaj- és agrokémiai vizsgálati módszerkönyv 1. A talaj fizikai, vízgazdálkodási és ásványtani vizsgálata. Inda 4231 Kiadó. Budapest. p. 357.

Di GlÉRIA, J., Klimes-SzMIK, A. \& DVORACSEK, M., 1957. Talajfizika és kolloidika. Akadémia Kiadó. Budapest.

Fedotov, G.N., Shein, E.V., Putlynev, V.I., ArKhangel'skaya, T.A., EliseeV, A.V. \& MilanOVSKII, E.Y. 2007. Physicochemical bases of differences between the sedimentometric and laser diffraction techniques of soil particle-size analysis. Eurasian Soil Science. 40. 281-288.

FILEP GY., 1995. Talajvizsgálat. Debreceni Agrártudományi Egyetem. Debrecen.

Fisher, P., Aumann, C., ChiA, K., O'Halloran, N. \& Chandra, S., 2017. Adequacy of laser diffraction for soil particle size analysis. PLoS ONE 12(5): e0176510. https://doi.org/10.1371/journal.pone.0176510

GeE G.W. \& OR D., 2002. Particle-Size Analysis. In: Methods of Soil Analysis, Part 4. Physical Methods (Eds.: DANE J.H. \& TOPP G.C.). Madison, WI. 255-293.

GeE, G. W. \& BAuder, J. W., 1986. Particle-size analysis. In: KLute, A. (ed.) Methods of soil analysis. Part 1. $2^{\text {nd }}$ ed. Agron. Monogr. 9. ASA and SSSA, Madison, WI. 383-411.

Genrich, D. A. \& Bremner, J. M., 1972. A reevaluation of the ultrasonic vibration method of dispersing soils. Soil Sci. Soc. Amer. Proc. 36. 944-947.

GOST (State Standard) 12536-79., 1979. Soils. Methods of laboratory particle-size and microaggregate-size distributions.

HALL, A.D., 1904. The mechanical analysis of soils and the composition of the fractions resulting therefrom. J. Chem. Soc. Trans. 85. 950-963.

ISO 11277: 2009 (E). Soil quality - Determination of particle size distribution in mineral soil material - Method by sieving and sedimentation. International Organization for Standarization, Geneva, Switzerland.

ISO/DIS 11277:1994. Soil quality; determination of particle size distribution in mineral soil material; method by sieving and sedimentation following removal of soluble salts, organic matter and carbonates.

IUSS WORKING GROUP WRB., 2015. World Reference Base for Soil Resources 2014, update 2015. International soil classification system for naming soils and creating legends for soil maps. World Soil Resources Reports No. 106. FAO, Rome.

JASSÓ F. (szerk.), 1989. '88 útmutató a nagyméretarányú országos talajtérképezés végrehajtásához. Agroinform Kiadó. Budapest.

JuRY, W.A., GARDNER, W.R. \& GARDNER, W.H., 1991. Soil Physics. 5th Edition, John Wiley and Sons, New York.

KACHINSKY, N.A., 1965. Soil Physics. Moscow. (in Russian)

KubotA, T., 1972. Aggregate-formation of allophanic soils: effect of drying on the dispersion of the soils. Soil Science and Plant Nutrition. 18. 79-87. 
LAVKULICS, L.M. \& WIENS, J.H., 1970. Comparison of organic matter destruction by hydgene peroxide and sodium hypochlorite and its effects on selected mineral constituents. Soil Sci. Soc. Am. Proc. 34. 755-758.

LIN, L. 1989. A concordance correlation coefficient to evaluate reproducibility. Biometrics. 45. 255-268.

Lin, L., HedAyAT, A.S., SinHA, B. \& YANG, M., 2002. Statistical methods in assessing agreement. Journal of the American Statistical Association. 97. 257-270.

MAKÓ, A. \& HERNÁDI, H., 2010. A talajok szemcseösszetételének vizsgálata során alkalmazott különböző előkészítési módszerek összehasonlító értékelése. In: TÖRÖK Á. \& VÁSÁRHELYI B. (szerk): Mérnökgeológia, kőzetmechanika. 101-108.

MaKó, A., Máté, F., Tóth, M., LÁszló, K. \& NÉMETH, T., 2002. A különböző szabványos módszerek szerint mért agyagtartalom és néhány egyéb talajfizikai paraméter összefüggésének vizsgálata. XVI. Országos Környezetvédelmi Konferencia és Szakkiállítás. Siófok. 2002. szeptember 11-13. 231-239.

Makó, A., Tóth, G., Weynants, M, Rajkai, K., Hermann, T., Tóth, B., 2017a. Pedotransfer functions for converting laser diffraction particle-size data to conventional values. European Journal of Soil Science, doi: 10.1111/ejss.12456.

MaKó A., VARGA T., Hernádi H., LABANCZ V. \& BARNA GY., 2017b. Talajminták lézeres szemcseanalízisének módszertani tapasztalatai. Agrokémia és Talajtan. 66. $223-250$

Mathieu, Cl. \& Pieltain, F., 2003. Analyse chimique des sols. Méthodes choisies. Editions Tec \& Doc - Lavoisier, Paris.

MatTHEWS, M.D., 1991. The effect of grain shape and density on the size measurement. In: Principles, methods, and applications of particle size analysis (Ed.: SYVITSKI, J.P.M.). Cambridge University Press. Cambridge. 22-33.

MikutTA, R., Kleber, M., KAISER, K. \& JAHN R., 2005. Review: organic matter removal from soils using hydrogen peroxide, sodium hypochlorite, and disodium peroxodisulfate. Soil Sci. Soc. Am. J. 69. 120-135.

Miller, M. P., RAdCliffe, D. E. \& Miller, D. M., 1988. An historical perspective on the theory and practice of soil mechanical analysis. J. Agron. Education. 17. 24 28.

Moeys, J., 2009. The Soil Texture Wizard R functions for plotting, classifying and transforming soil texture data Pedometron. 28. 7-10.

MoEys, J., 2014. The soil texture wizard: R functions for plotting, classifying, transforming and exploring soil texture data. http://cran.rproject.org/web/packages/soiltexture/vignettes/soiltexture_vignette.pdf

MSZ-08-0205-78. MÉM Ágazati Szabvány 1979. A talaj fizikai és vízgazdálkodási tulajdonságainak vizsgálata, Budapest.

MSZ-08-0206-2-78. MÉM Ágazati Szabvány 1979. A talaj egyes kémiai tulajdonságainak vizsgálata. Laboratóriumi vizsgálatok (pH-érték, szódában kifejezett fenolftalein lúgosság, vízben oldható összes só, hidrolitos /y1-érték/ és kicserélődési aciditás /y2-érték/).

Nemes, A., Wösten, J.H.M., Lilly, A., Oude VoshaAR, J.H., 1999. Evaluation of different procedures to interpolate particle-size distributions to achieve compatibility within soil databases. Geoderma. 90. 187--202. 
R CORE TEAM, 2013. R: A language and environment for statistical computing. $\mathrm{R}$ Foundation for Statistical Computing, Vienna, Austria. URL http://www.Rproject.org/.

RoDERICK, G.L., 1966. A history of particle-size limits. Special report. Iowa State University. http://publications.iowa.gov/17268/1/IADOT_hr99_History_Particle_Limits.pdf

RYŻAK, M. \& BIEGANOWSKI, A., 2011. Methodological aspects of determining soil particle-size distibution using the laser diffraction method. J. Plant Nutr. Soil Sci. 174. 624-633.

Schulte, P., Lehmkuhl, F., Steininger, F., Loibl, D., Lockot, G., Protze, J., FISCHER, P. \& STAUCH, G., 2016. Influence of $\mathrm{HCl}$ pretreatment and organomineral complexes on laser diffraction measurement of loess-paleosol-sequences. Catena. 137. 392-405.

SHAw, T.M. \& ALEXANDER, L.T., 1936. A note on mechanical analysis and soils texture. Soil Sci. Soc. Amer. Proc.Proceedings of Soil Science Society of America. 1. 303-304.

SHEIN, E.V., 2009. The particle-size distribution in soils: problems of the methods of study, interpretation of the results, and classification. Eurasian Soil Science. 42. 284-291.

SIMONOFF, J.S., 1996. Smoothing methods in statistics. Springer-Verlag, New York.

SOCHAn, A., BIEGANOWski, A. BARTMIŃSKI, P., RYŻAK, M., BRZEZIŃSKA, M., DĘBICKI, R., STUCZYŃSKI, T. \& POLAKOWSKI, C., 2015. Use of the laser diffraction method for assessment of the pipette method. Soil Sci. Soc. Am. J. 79. 37-42.

Sochan, A., BIEganowski, A., RYŻAK, M., Dobrowolski, R. \& BARTMiński, P., 2012. Comparison of soil texture determined by two dispersion units of Mastersizer 2000. Int. Agrophys. 26. 99-102.

SZABOLCS I. (Szerk.), DARAB K., FÓRIZS J.-NÉ, FÖLDVÁRI GY., JASSÓ F. \& VÁRALLYAY GY., 1966. A genetikus üzemi talajtérképezés módszerkönyve. Országos Mezőgazdasági Minőségvizsgáló Intézet (OMMI). Budapest.

Tóth, B., Weynants, M., Nemes, A., MaKó, A., Bilas, G. \& Tóth, G. 2015. New generation of hydraulic pedotransfer functions for Europe. European Journal of Soil Science., 66,. 226-238.

TóтH G., 2009. Hazai szántóink minősítése a D-e-Meter rendszerrel. Agrokémia és Talajtan. 58. 227-242.

USDA, 1993. Soil Survey Division Staff. Soil survey manual. 18. chapter 3. Soil Conservation Service. U.S. Department of Agriculture. http://soils.usda.gov/technical/manual/print_version/chapter3.html.

VenABLES, W.N. \& RiPleY, B.D., 2002. Modern applied statistics with S. Fourth edition. Springer.

YANG, H., 2013. The case for being automatic: introducing the automatic linear modeling (LINEAR) procedure in SPSS Statistics. Multiple Linear Regression Viewpoints. 39. 27-37. 


\title{
Particle size distribution analysis using the pipette method: comparison and conversion of Hungarian and international standards
}

\author{
${ }^{1}$ A. Makó, ${ }^{1,2 *}$ H. Hernádi, ${ }^{1}$ G. Barna, ${ }^{3}$ R. Balázs, ${ }^{1}$ S. MolnáR, ${ }^{4}$ V. Labancz, ${ }^{1,2}$ B. \\ TóTH and ${ }^{1} \mathrm{Z}$. BAKACSI \\ ${ }^{1}$ Institute for Soil Science and Agricultural Chemistry, Centre for Agricultural \\ Research, Hungarian Academy of Sciences, Budapest \\ ${ }^{2}$ Department of Crop Production and Soil Science, Georgikon Faculty, University of \\ Pannonia, Keszthely \\ ${ }^{3}$ Institute for Geological and Geochemical Research, Research Centre for Astronomy \\ and Earth Sciences, Hungarian Academy of Sciences, Budapest \\ ${ }^{4}$ Department of Soil Science and Agricultural Chemistry, Institute of Environmental \\ Sciences, Faculty of Agricultural and Environmental Sciences, Szent István University, \\ Gödöllő
}

\section{Summary}

The particle size distribution (PSD) values obtained for a soil database representing the main Hungarian soil types using the Hungarian standard (MSZ-080205-78) and the international standard (ISO/DIS 11277:1994) were compared with the pipette method. The relationship between these PSDs and other physical soil characteristics (upper limit of plasticity according to Arany, water vapour adsorption according to Sík) was also analysed, and a suggestion was made of how these results could be converted into each other.

Experience showed that the pre-treatments applied as part of the ISO/DIS method may change the ratio of particle size fractions: there was a significant increase in the clay content, while the silt content decreased to a lesser and the sand content to a greater extent, possibly because some of the particles remain in microaggregate form when the MSZ method is used. The results confirmed the greater accuracy of the ISO/DIS method: the clay contents measured with the ISO/DIS method exhibited stronger correlations with the upper limit of plasticity according to Arany and with hygroscopicity values than those measured with the MSZ method.

The estimated ISO/DIS fractions became much closer to the measured ones when the suggested pedotransfer functions were applied. The conversion method proved to be more reliable for the prediction of clay and sand content than for silt content. In its present form the estimation method is not suitable for replacing the ISO/DIS method, but it could be of good service in research and comparative analysis in cases where only the MSZ method can be used or where only old MSZ PSD data exist. 
Key words: particle size distribution, pre-treatment methods, pedotransfer functions

\section{Tables and figures}

Table 1. Main parameters of the PSD soil database. (1) Parameter. (2) Mean. (3) Deviation. ${ }^{\mathrm{a}}$, clay fraction $(<0.002 \mathrm{~mm})$; $^{\mathrm{b}}$, silt fraction $(0.002-0.05 \mathrm{~mm}){ }^{\mathrm{c}}$, sand fraction $(0.05-2.0 \mathrm{~mm})$, after preparation according to the international (ISO/DIS) and Hungarian (MSZ) standards ( $\mathrm{N}=339$ ).

Table 2. Suggested pedotransfer functions to estimate ISO/DIS clay, silt and sand fractions. (1) estimated clayISO/DIS (2) estimated sand ISO/DIS $_{\text {(3) }}$ (3) estimated silt ${ }_{\text {ISO/DIS; }}{ }^{2} \mathrm{~A}_{\mathrm{MSZ}}, \mathrm{P}_{\mathrm{MSZ}}, \mathrm{H}_{\mathrm{MSZ}}$ : clay, silt and sand fractions measured by the MSZ method (<0.002 mm, 0.002-0.05 mm, >0.05 mm) (\%); OM: humus content (\%); $\mathrm{CA}: \mathrm{CaCO}_{3}$ content (\%); $\mathrm{pH}_{\mathrm{DV}}$ : $\mathrm{pH}$ measured in distilled water. Estimated silt ${ }_{\text {ISO/DIS }}=100-($ estimated clay ISO/DIS + estimated sand ISO/DIS $)$.

Figure 1. Origin of the soil profiles making up the PSD soil database (number of soil profiles in brackets).

Figure 2. Comparison of the particle size fractions measured using the two methods. (1) Clay. (2) Silt. (3) Sand.

Figure 3. Relationship between the clay contents measured using the two methods and the upper limit of plasticity according to Arany and the hygroscopicity value according to Sík.

Figure 4. Accuracy and reliability of the suggested conversion functions $\left(\mathrm{R}^{2}\right.$ : coefficients of determination for fractions measured using the MSZ and ISO/DIS methods, and for ISO/DIS fractions estimated from MSZ fractions or measured; root mean square errors (RMSE) of fractions measured using the MSZ and ISO/DIS methods, and of ISO/DIS fractions estimated from MSZ fractions or measured (w/w\%) (1) Training dataset. (2) Test dataset. (3) Clay. (4) Silt. (5) Sand. (6) Datasets. (7) PSD fractions.

Figure 5. Comparison of PSD values measured using the two methods or estimated with pedotransfer functions on USDA textural triangles, presented using Kernel density functions. (1) Clay. (2) Silt. (3) Sand. (4) Estimated.

Figure 6. Spatial distance of PSD point pairs between a) MSZ PSD and ISO/DIS PSD; b) measured ISO/DIS PSD and ISO/DIS PSD estimated from measured MSZ PSD (larger bubbles represent point pairs that are farther apart and smaller ones those that are closer together); c) ratio of this distance for each sample. 